\title{
Karakterisasi Self-Nanoemulsifying Drug Delivery System (SNEDDS) Minyak Buah Merah (Pandanus conoideus Lam.)
}

Nurul Huda \& Iis Wahyuningsih*

Fakultas Farmasi Universitas Ahmad Dahlan, Yogyakarta

*Corresponding author: Iis.wahyuningsih@pharm.uad.ac.id

\begin{abstract}
Background: Breast cancer ranked second in Indonesia after cervical cancer in which women were being the major patient in this disease. One of the new medicine discovered was from natural substance that showed a pharmacological effect in overcoming cancer, it is called red fruit oil (Pandanus conoideus Lam.). Red fruit oil contain many antioxidant compounds that assisted the healing process of cancer by preventing and suppressing the growth of the cancer cells. However, giving red fruit oil directly to the patients by oral administration is not acceptable, it requires the development of delivery systems such as SNEDDS (Self-Nanoemulsifying Drug Delivery System). Objective: This research aim to get SNEDDS characteristic on red fruit oil. Methods: To obtain a good SNEDDS characters, the suitable comparison of the oil surfactants and co-surfactants need to be investigated. In this study 4 formulas containing different composition of red fruit oil and the tween 80 and propylene glycol were tested. Thee formulas were I (9:62:29), II (9:68:23), III (11:64:25) and IV (12:65:23). The \%Transmittant, emulsification time and the $I C_{50}$ of each formulas were determined. Results: The results showed that the \% transmittants of formula 1-IV were 99.21\%; 99.34\%; 98.69\% and 98.27, respectively. The results obtained for the emulsification time of the 4 formulas in consecutive were 16.51; 15.40; 17.64 and 18.67 seconds. The IC $C_{50}$ values of the 4 formulas were $176.81 ; 58.99 ; 6832.02$ and $514.84 \mu \mathrm{L} / \mathrm{mL}$, respectively. Conclusions: The results indicated that the best SNEDDS character was obtained from formula II which showed the highest \% Transmittant, the fastest emulsification time and the smallest $I C_{50}$ value.
\end{abstract}

Keyword : red fruit oil, SNEDDS, characteristics of SNEDDS

\begin{abstract}
Abstrak
Pendahuluan: Kanker payudara di Indonesia menempati posisi kedua yang banyak diderita khususnya oleh kaum wanita setelah kanker serviks. Salah satu penemuan obat baru yang berasal dari bahan alam yang menunjukkan efek farmakologis dalam mengatasi kanker adalah Minyak Buah Merah (Pandanus conoideus Lam.). Minyak Buah Merah mengandung banyak senyawa antioksidan yang membantu proses penyembuhan penyakit kanker dengan mencegah dan menekan perkembangan sel-sel kanker. Namun, pemberian Minyak Buah Merah secara langsung per oral tidak acceptable sehingga diperlukan pengembangan sistem penghantaran seperti SNEDSS (Self-Nanoemulsifying Drug Delivery System). Tujuan: Penelitian ini bertujuan untuk mendapatkan karakteristik SNEDDS pada Minyak Buah Merah. Metode: Untuk mendapatkan karakter SNEDDS yang baik perlu dicari perbandingan minyak, surfaktan dan ko-surfaktan yang sesuai. Dibuat 4 formula dengan variasi perbandingan Minyak Buah Merah, tween 80, propilen glikol pada formula 1 (9:62:29), formula 2 (9:68:23), formula 3 (11:64:25) dan formula 4 (12:65:23). Selanjutnya SNEDDS dibuat dengan mencampur ketiga komponen tersebut. Kemudian keempat formula ditentukan \% Transmitan, waktu emulsifikasi dan nilai $\mathrm{IC}_{50}$ untuk menilai karakter SNEDDS yang baik. Hasil: Hasil dari penelitian diperoleh \% Transmitan dari 4 formula berturut-turut yaitu 99,21\%; 99,34\%; 98,69\% dan 98,27\%. Hasil yang diperoleh untuk waktu emulsifikasi dari 4 formula berturut-turut adalah 16,$51 ; 15,40 ; 17,64$ dan 18,67 detik. Nilai IC $_{50}$ untuk 4 formula diperoleh hasil berturutturut sebesar 176,81; 58,99; 6832,02 dan $514,84 \mu \mathrm{L} / \mathrm{mL}$. Kesimpulan: Dilihat dari hasil pengujian tersebut didapatkan formula yang menghasilkan SNEDDS paling baik yaitu pada formula 2 karena mempunyai $\%$ Transmitan paling besar, waktu emulsifikasi paling cepat dan nilai $\mathrm{IC}_{50}$ paling kecil.
\end{abstract}

Kata kunci : minyak buah merah, SNEDDS, karakteristik SNEDDS 


\section{PENDAHULUAN}

Kanker payudara di Indonesia menempati posisi kedua sebesar 12,10\% setelah kanker serviks 19,18\% (Meiyanto dkk., 2006). Pengobatan kanker yang dilakukan sampai sekarang meliputi radioterapi $(70 \%)$, pembedahan $(20-25 \%)$ dan kemoterapi $(5-10 \%)$ (Tjindarbumi, 2002), namun Hamid (2008) menyatakan bahwa pengobatan kanker tersebut hanya efektif untuk beberapa periode waktu saja dan bersifat merusak seluruh sel termasuk sel yang normal sekalipun. Selain itu, pada umumnya penderita kanker kurang dapat bertahan dengan efek samping yang timbul dari pengobatan yang diberikan (Sumarawati \& Fatmawati, 2011). Tindakan pembedahan juga mempengaruhi keadaan badan dan kekebalan, misalnya terjadi perubahan perbandingan antara berbagai macam sel darah putih (Jong, 2002). Di sisi lain banyak obat sitostatika yang telah resisten terhadap sel kanker, sehingga pertumbuhan sel kanker yang seharusnya dihambat aktivitasnya malah akan semakin tidak terkendali pertumbuhannya. Salah satu upaya yang dilakukan untuk mengatasi permasalahan tersebut adalah dengan penemuan obat baru yang berasal dari bahan alam yang menunjukkan efek farmakologis dalam mencegah dan mengobati penyakit kanker (Mangan, 2003).

Salah satu sumber alam lokal yang berpotensi sebagai antikanker adalah buah merah (Pandanus conoideus Lam.). Buah ini merupakan buah asli Papua yang banyak mengandung senyawa aktif antara lain tokoferol, alfa-tokoferol, beta-karoten, protein, kalsium, besi, fosfor, vitamin $\mathrm{C}$, asam palmitoleat, asam oleat, asam linoleat, dan asam alfa-linoleat. Kandungan kimia terbesar dari buah tersebut adalah tokoferol (11000 ppm), beta-karoten (700 ppm), dan karoten (12000 ppm) dimana masing- masing senyawa tersebut mempunyai efek sebagai antioksidan sehingga mampu menangkal radikal bebas dan meningkatkan sistem kekebalan tubuh. Ketiga senyawa ini juga yang membantu proses penyembuhan penyakit kanker dengan mencegah dan menekan perkembangan sel-sel kanker (Budi \& Paimin, 2005).

Pengujian sari buah merah terhadap efek antikanker telah dilakukan pada sel kanker rahim, sel kanker payudara T47D dan sel kanker usus besar CC531. Efek pada sel kanker rahim dan sel kanker usus besar CC531 lebih besar dari pada sel kanker payudara. Diperoleh nilai $\mathrm{IC}_{50}$ sari buah merah pada sel kanker usus besar adalah 200 ppm sedangkan pada sel kanker payudara T47D adalah $600 \mathrm{ppm}$. Aktivitas antikanker dari sari buah merah ini ternyata lebih besar dibandingkan agen kemoterapi doksorubisin (Moeljopawiro dkk., 2007).

Pemberian Minyak Buah Merah secara langsung per oral dipandang tidak acceptable oleh masyarakat karena dirasa kurang nyaman, selain itu minyak tidak mudah diabsorpsi dalam saluran cerna karena bersifat hidrofobik sehingga sukar larut di dalam saluran pencernaan (Shargel dkk., 2005). Diperlukan pengembangan sistem penghantaran Minyak Buah Merah yang lebih acceptable. Salah satu sistem penghantaran obat yang dapat digunakan untuk mengatasi masalah di atas adalah SNEDDS (SelfNanoemulsifying Drug Delivery System).

SNEDDS adalah salah satu formulasi nanopartikel berbasis minyak atau lemak. SNEDDS merupakan campuran isotropik antara minyak, surfaktan, dan ko-surfaktan yang dapat membentuk nanoemulsi secara spontan ketika kontak dengan cairan lambung (Sun \& Han, 2011; Makadia dkk., 2013). Formulasi sediaan SNEDDS akan meningkatkan disolusi dari zat aktif dengan cara memfasilitasi pembentukan fase tersolubilisasi dan meningkatkan transpor melalui sistem limfatik usus, serta menghindari effluks P-gp, sehingga dapat meningkatkan absorpsi dan bioavailabilitas zat aktif dari saluran cerna (Singh dkk., 2009).

Karakteristik SNEDDS dipengaruhi oleh komponen penyusunnya, yaitu fase minyak, surfaktan dan ko-surfaktan. Komponen minyak dalam formulasi SNEDDS berperan dalam menentukan ukuran emulsi yang terbentuk serta kapasitas zat aktif yang dapat dibawa karena minyak merupakan pembawa utama zat aktif dalam SNEDDS (Date dkk., 2010). Surfaktan berperan dalam memperkecil ukuran tetesan emulsi, serta menjaga zat aktif dalam jangka waktu lama pada tempat absorpsi, sehingga tidak terjadi pengendapan dalam saluran cerna. Tween 80 merupakan surfaktan non-ionik dengan nilai HLB 15 yang stabil untuk emulsi o/w dan aman bagi tubuh. Ko-surfaktan dalam formulasi SNEDDS dapat membantu surfaktan dalam menurunkan tegangan permukaan air dan minyak, meningkatkan disolusi dari zat aktif, serta memperbaiki dispersibilitas dan absorpsi zat aktif. Propilen glikol merupakan ko-surfaktan yang dapat membantu absorpsi obat (Rowe dkk., 2009). Tujuan penelitian ini untuk mengetahui pengaruh perbandingan minyak, surfaktan dan ko-surfaktan dalam formula SNEDDS Minyak Buah Merah terhadap nilai \%Transmitan, waktu emulsifikasi dan $\mathrm{IC}_{50}$. 


\section{BAHAN DAN METODE}

\section{Bahan}

Bahan yang digunakan adalah Minyak Buah Merah yang diperoleh dari supplier PT. TMS, Tween 80, propilen glikol (pharmaceutical grade) diperoleh dari supplier PT Brataco, aqua bidestilata, media RPMI (Rosewall Park Memorial Institute) (Gibco), sel T47D, larutan FBS (Fetal Bovine Serum) (Gibco), Natrium Bikarbonat $\left(\mathrm{NaHCO}_{3}\right)$, Asam Klorida $(\mathrm{HCl})$, HEPES ( $N$-2-hydroxylethil piperazine-N-2-ethane sulfonic acid), Penicillin-Streptomycin (Sigma), Fungison (Sigma), PBS (Phosphate Buffer Saline), SDS (Sodium Dodecyl Sulphate), MTT [3-(4-5-dimetilthiazol-2-il) $-2,5$ difenil tetrazolium bromid] dan DMSO.

Alat

Alat yang digunakan dalam penelitian ini adalah oven, Flowcytometry, ELISA plate reader, ShimadzuGCMS 2010S mass selective detector (Gas Chromatography-Mass Spechtroscopy), $\mathrm{pH}$ meter (Hanna), ultra sentrifuge (eppendorf centrifuge
5804 R), LAF (Laminar Air Flow), autoklaf, haemocytometer, inkubator sel dengan aliran oksigen 95\% dan karbondioksida 5\%, cell counter, filter bakteri 0,2 mikroliter steril, 96-well plate dan vortex.

\section{Metode}

Identifikasi minyak buah merah (pandanus conoideus lam)

Identifikasi Minyak Buah Merah (Pandanus conoideus Lam) dilakukan dengan menggunakan GC-MS (Gas Chromatography-Mass Spechtroscopy) di Laboratorium Terpadu Fakultas Farmasi Universitas Ahmad Dahlan Yogyakarta.

\section{Pembuatan SNEDDS minyak buah merah}

Sediaan SNEDDS Minyak Buah Merah dibuat seperti formula yang tersaji pada Tabel 1 dengan cara mencampur surfaktan Tween 80 dan ko-surfaktan propilen glikol kemudian dihomogenkan dengan vortex selama 1 menit. Minyak Buah Merah ditambahkan ke dalam campuran tersebut dan dihomogenkan kembali menggunakan vortex selama 1 menit.

Tabel 1. Formula SNEDDS Minyak Buah Merah (Harumawati, 2016)

\begin{tabular}{cccc}
\hline Formula & MBM $(\%)$ & $\begin{array}{c}\text { Tween } \\
80(\%)\end{array}$ & $\begin{array}{c}\text { Propilen glikol } \\
(\%)\end{array}$ \\
\hline 1 & 9 & 62 & 29 \\
2 & 9 & 68 & 23 \\
3 & 11 & 64 & 25 \\
4 & 12 & 65 & 23 \\
\hline
\end{tabular}

\section{Karakteristik SNEDDS minyak buah merah Uji Transmitan}

Pengamatan kejernihan dilakukan secara spektrofotometri dengan melarutkan $100 \mu \mathrm{L}$ SNEDDS Minyak Buah Merah ke dalam $5 \mathrm{~mL}$ akuades yang dihomogenkan dengan bantuan vortex mixer selama 1 menit dan diukur absorbansinya pada panjang gelombang $650 \mathrm{~nm}$ dengan blanko akuades. Nilai absorbansi yang mendekati $100 \%$ menunjukkan bahwa ukuran tetesan dispersi yang dihasilkan oleh SNEDDS telah mencapai ukuran nanometer, yang secara visual tampak dari transparansi sistem yang terbentuk (Bali dkk., 2010).

\section{Uji waktu emulsifikasi}

Penentuan waktu emulsifikasi menggunakan alat disolusi aparatus tipe II. Tiap formula ditambahkan $900 \mathrm{~mL} \mathrm{HCl} 0,1 \mathrm{~N}$ pada suhu $37^{\circ} \mathrm{C}$. Pada alat disolusi diatur seperti agitasi ringan pada saluran cerna yaitu dengan kecepatan pengaduk $50 \mathrm{rpm}$. Waktu emulsifikasi dinilai secara visual. Syarat waktu emulsifikasi yang baik untuk SNEDDS adalah kurang dari 1 menit (Chintalapudi dkk., 2015).

\section{Uji Sitotoksik}

\section{Preparasi sel T47D}

Sel yang inaktif dalam wadah ampul diambil dari tangki nitrogen cair dan segera dicairkan dalam penangas air pada suhu $37^{\circ} \mathrm{C}$ sampai gumpalan di dalam ampul mencair, kemudian ampul disemprot dengan etanol $70 \%$. Ampul dibuka dan sel dipindahkan ke dalam ruang Laminar Air Flow dan suspensi sel dihomogenkan dengan centrifuge pada kecepatan $3000 \mathrm{rpm}$ selama 10 menit. Supernatan dibuang, pellet ditambah $1 \mathrm{~mL}$ medium RPMI 1640 yang mengandung $10 \%$ FBS dan disuspensikan hingga homogen, selanjutnya sel ditumbuhkan dalam beberapa petri dish flask kecil (3 - 4 buah), diinkubasikan dalam inkubator suhu $37^{\circ} \mathrm{C}$ dengan aliran $\mathrm{CO}_{2} 5 \%$ dan tutup flask dilonggarkan. Setelah 24 jam, medium diganti dan sel ditumbuhkan lagi hingga konfluen (sel telah memenuhi flask) dan jumlahnya cukup untuk penelitian. 


\section{Panen sel}

Setelah jumlah sel cukup, medium dibuang dan sel dicuci koloninya. Larutan tersebut dibuang, lalu ditambah larutan tripsin 2,5\% sebanyak $1 \mathrm{~mL}$. Supaya distribusi sel merata maka ditambah larutan PBS $3 \mathrm{~mL}$, didiamkan sekitar 3 - 5 menit agar tripsin bekerja dengan baik. Sel kemudian dipindah ke dalam tabung conical steril dan ditambah PBS sampai volume $10 \mathrm{~mL}$ dan disentrifuge $3000 \mathrm{rpm}$ selama 10 menit. Sel dicuci dua kali dengan medium yang sama dan dihitung jumlah selnya menggunakan haemocytometer. Jumlah sel dihitung dengan rumus :

$\frac{\text { Jumlah sel dalam } 4 \text { bilik x } 10^{4} \mathrm{sel} / \mathrm{mL}}{4}$

(Doyle and Griffiths, 2000)

Suspensi sel ditambah dengan sejumlah medium kultur sehingga diperoleh konsentrasi sel sebesar yang diperlukan.

\section{Uji sitotoksik dengan metode MTT}

Sel dengan konsentrasi $5 \times 10^{4} \quad$ sel/100 $\mu \mathrm{L}$ didistribusikan ke dalam sumuran (menggunakan 96-well plate) sebanyak $100 \mu \mathrm{L}$ pada tiap sumuran dan diinkubasi selama 24 jam di dalam inkubator $\mathrm{CO}_{2} 5 \%$ agar sel beradaptasi dan menempel di sumuran. Selanjutnya pada tiap sumuran ditambahkan $100 \mu \mathrm{L}$ larutan uji dengan kadar bervariasi sesuai yang telah ditetapkan, lalu diinkubasi kembali selama 24 jam. Sebagai kontrol digunakan larutan DMSO $1 \%$. Pada akhir inkubasi, media kultur dibuang dengan jalan disedot hati-hati dan sel dicuci dengan $100 \mu \mathrm{L}$ PBS. Pada masing-masing sumuran, kemudian ditambahkan $100 \mu \mathrm{L}$ media kultur dan $10 \mu \mathrm{L}$ larutan MTT $5 \mathrm{mg} / \mathrm{mL}$.

Sel diinkubasi kembali selama 4 jam dalam inkubator $\mathrm{CO}_{2} 5 \%$ dengan suhu $37^{\circ} \mathrm{C}$. Sel yang hidup akan bereaksi dengan MTT membentuk formazan yang berwarna ungu-biru tua. Reaksi MTT dihentikan dengan stopper reagent (Sodium dodesil sulfat), kemudian diinkubasi pada suhu kamar dalam ruang gelap selama semalam. Selanjutnya, absorbansi tiap sumuran dibaca dengn ELISA reader (Bencmark Bio Rad) pada panjang gelombang $595 \mathrm{~nm}$ (Sinaga dkk., 2011).

\section{Analisis Data}

\section{Uji sitotoksik}

Data yang diperoleh berupa absorbansi masingmasing sumuran dikonversi ke dalam persen sel hidup. Persen kehidupan (\% viabilitas $\quad$ sel) dihitung menggunakan rumus:

$\%$ viable cells $=\frac{\text { Absorbansi perlakuan-absorbansi media }}{\text { Absorbansi kontrol-absorbansi media }} \times 100 \%$
Hasil perhitungan viabilitas sel yang diperoleh dari masing-masing konsentrasi, kemudian dilanjutkan dengan uji korelasi untuk menentukan persamaan regresi linear dan menentukan harga $\mathrm{IC}_{50}$. Nilai $\mathrm{IC}_{50}$ diperoleh dengan persamaan regresi linear $(y=b x+a)$ dari grafik antara log konsentrasi versus $\%$ sel hidup dimana nilai $\mathrm{r}$ dikatakan linear jika lebih besar dari $r_{\text {tabel }}$ kemudian dimasukkan nilai $y=50$ pada persamaan regresi linear dan dicari $x$ nya, kemudian ditentukan antilog dari konsentrasi tersebut maka diperoleh $\mathrm{IC}_{50}$ (Fakultas Farmasi UGM, 2009).

\section{HASIL DAN PEMBAHASAN}

\section{Skrining minyak buah merah}

Senyawa yang terkandung dalam Minyak Buah Merah dianalisis menggunakan Gas Chromatography (GC). Senyawa yang terdeteksi diidentifikasi melalui set data massa spektrum yang ada pada instrumen. Komponen utama yang teridentifikasi adalah octadec9-enoicacid $(11,27 \%), \quad$ dodecanoic acid, 1,2,3-propanetriyl ester $(8,54 \%)$ dan hexadecanoic acid (2,61\%). Penelitian Rohman dkk., (2012) tentang karakterisasi Minyak Buah Merah (Pandanus conoideus) menunjukkan bahwa senyawa yang paling dominan dari golongan asam lemak tak jenuh adalah asam oleat $(68,80 \%)$, asam palmitat $(20,05 \%)$ dan asam linoleat $(8,49 \%)$. Senyawa volatile yang paling dominan dalam Minyak Buah Merah adalah 1,3-dimethylbenzene $\quad(27,46 \%), \quad N$-glycyl-L-lanin $(17,36 \%)$, trichloromethane $(15,22 \%)$ dan etana $(11,43 \%)$. Kandungan senyawa Minyak Buah Merah hasil penelitian Noviyanti (2010) yang melakukan modifikasi kromatografi kolom untuk pemisahan trigliserida dari ekstrak buah merah (Pandanus conoideus) mendapatkan hasil golongan asam lemak tak jenuh metil oleat $(56,21 \%)$, metil palmitat $(14,33 \%)$, asam linoleat $(5,25 \%)$, dan asam linolenat $(3,24 \%)$.

Data GC-MS Minyak Buah Merah yang diperoleh dari penelitian ini menunjukkan bahwa senyawa yang dihasilkan berupa asam lemak. Hasil analisa mendapatkan persentase asam lemak yang terbesar adalah asam enoat $(11,27 \%)$. Hasil penelitian ini berbeda dengan hasil penelitian Rohman (2012) maupun Noviyanti (2010). Hal ini kemungkinan disebabkan faktor seperti tempat tumbuh yang berbeda, metode pembuatan minyak yang berbeda atau saat penentuan kadar menggunakan kondisi GC-MS yang berbeda. 


\section{Karakteristik SNEDDS minyak buah merah \% Transmitan}

Kejernihan yang diukur dalam persen Transmitan adalah salah satu kontrol terhadap pembentukan dispersi dari SNEDDS. Pengamatan kejernihan secara visual merupakan parameter kualitatif spontanitas dispersi (Xi dkk., 2009). Nilai Transmitan yang mendekati $100 \%$ menunjukkan bahwa SNEDDS menghasilkan dispersi jernih dan transparan dengan ukuran tetesan diperkirakan mencapai nanometer (Bali dkk., 2010). Untuk memastikan tingkat kejernihan nanoemulsi yang terbentuk selanjutnya dilakukan pembacaan Transmitan dengan menggunakan spektrofotometri dengan panjang gelombang $650 \mathrm{~nm}$ (Rawat dkk., 2014; Patel dkk., 2014).

Ukuran fase terdispersi sangat mempengaruhi penampilan emulsi akan jernih atau keruh, hal ini karena ukuran droplet-droplet minyak yang terdispersi dalam air. Bila sistem emulsi yang memiliki ukuran droplet sangat kecil dilewati cahaya, maka berkas cahaya akan diteruskan sehingga warna larutan terlihat transparan dan Transmitan yang dihasilkan semakin besar (Sahumena, 2014). Hasil pembacaan Transmitan 4 formula SNEDDS tersaji pada Tabel 2.

Tabel 2. \% Transmitan SNEDDS Minyak Buah Merah

\begin{tabular}{ccccc}
\hline Formula & $\begin{array}{c}\text { MBM } \\
(\%)\end{array}$ & $\begin{array}{c}\text { Tween } 80 \\
(\%)\end{array}$ & $\begin{array}{c}\text { Propilen glikol } \\
(\%)\end{array}$ & $\begin{array}{c}\text { Rata-Rata } \\
\text { ransmitan }(\%) \\
\pm \text { SD }\end{array}$ \\
\hline 1 & 9 & 62 & 29 & $99,21 \pm 0,228$ \\
2 & 9 & 68 & 23 & $99,34 \pm 0,085$ \\
3 & 11 & 64 & 25 & $98,69 \pm 0,189$ \\
4 & 12 & 65 & 23 & $98,27 \pm 0,114$ \\
\hline
\end{tabular}

Keterangan :

Nilai signifikansi $<0,05$ diperoleh dari semua formula, kecuali antara formula 1 dan formula 2 . Ada perbedaan nilai $\%$ Transmitan dari formula 1 dan 3, formula 1 dan 4 , formula 2 dan 3, formula 2 dan 4 serta formula 3 dan 4 .

Hasil uji Transmitan pada Tabel 2 menunjukkan bahwa SNEDDS Minyak Buah Merah menghasilkan dispersi yang jernih secara visual dengan nilai Transmitan berkisar 98,27 - 99,34\%. Hasil pengujian kejernihan formula SNEDDS Minyak Buah Merah menghasilkan dispersi jernih dengan nilai Transmitan lebih dari $90 \%$, menandakan bahwa ukuran tetesan yang dihasilkan kecil. Hal tersebut dikarenakan penggunaan Tween 80 sebagai surfaktan yang mampu membentuk sistem nanoemulsi $o / w$ secara spontan saat didispersikan dalam cairan lambung (Kommuru dkk., 2001). Hasil tersebut didukung pula oleh penggunaan ko-surfaktan yaitu propilen glikol yang dapat membantu kelarutan dari Tween 80 maupun kelarutan dari obat dalam basis minyak (Amrutkar dkk., 2014).

Berdasarkan hasil \% Transmitan yang diperoleh menunjukkan hasil yang paling besar pada formula 2 sebesar 99,34\% diikuti oleh formula 1 sebesar 99,21\%, dimana kedua formula ini mempunyai komposisi minyak yang sama yaitu sebanyak $9 \%$ namun diperoleh hasil \% Transmitan yang berbeda. Hal ini disebabkan karena perbandingan antara Tween 80 dan propilen glikol yang berbeda, dimana formula 2 mempunyai komposisi Tween 80 lebih banyak yaitu $68 \%$ sedangkan pada formula 1 lebih sedikit hanya $62 \%$.
Komposisi fase minyak yang sama dengan Tween 80 yang lebih besar dapat mempengaruhi ukuran tetesan emulsi sehingga semakin kecil ukuran yang dihasilkan semakin jernih SNEDDS yang diperoleh, maka \% Transmitan semakin besar.

Pada formula 3 diperoleh \% Transmitan yang semakin rendah yaitu 98,69\% karena di dalam formula 3 mengandung komposisi minyak sebesar $11 \%$ dan komposisi surfaktan 64\%, dimana semakin tinggi komposisi fase minyak diperlukan surfaktan yang lebih banyak pula untuk dapat melingkupi zat aktif tersebut. Formula 4 dengan komposisi minyak sebesar $12 \%$ dan komposisi surfaktan sebanyak $65 \%$, diperoleh hasil $\%$ Transmitan yang semakin rendah lagi dari formula 3 yaitu 98,27\%, hal ini juga disebabkan karena fase minyak yang semakin tinggi namun komposisi surfaktan yang dipakai kurang dapat melingkupi Minyak Buah Merah.

Pada keempat formula ini komposisi ko-surfaktan tidak terlalu mempengaruhi hasil \%Transmitan, karena dilihat dari formula 2 dan 4 yang mempunyai komposisi propilen glikol yang sama yaitu $23 \%$ akan tetapi terdapat perbedaan hasil \% Transmitan yang diperoleh. Semakin tinggi komposisi minyak, maka komposisi surfaktan juga harus semakin besar agar 
mampu melingkupi minyak sehingga diperoleh ukuran partikel yang kecil sehingga penampilan SNEDDS semakin jernih dengan \% Transmitan yang besar mendekati $100 \%$.

\section{Waktu emulsifikasi}

Waktu emulsifikasi dilakukan untuk menentukan seberapa cepat formula SNEDDS membentuk emulsi (Zhao, 2015). Suatu formula SNEDDS harus mampu membentuk emulsi secara spontan setelah kontak langsung dengan cairan gastrik, hal tersebut merupakan parameter penting dalam formulasi SNEDDS. Emulsifikasi secara spontan dapat terjadi ketika sediaan SNEDDS mampu membentuk emulsi tanpa adanya proses pengocokan yang berarti. Pemilihan minyak, surfaktan dan ko-surfaktan dalam formula SNEDDS sangat penting dalam kaitannya terhadap terjadinya emulsifikasi spontan ketika berada pada saluran cerna (Sahumena, 2014), semakin cepat waktu emulsifikasi maka akan meningkatkan absorpsi dari obatnya (Kaur dkk., 2013).

Jika waktu emulsifikasi yang dihasilkan kurang dari 1-2 menit maka formula SNEDDS mampu membentuk emulsi setelah langsung kontak dengan cairan gastrik, dengan menghasilkan sistem emulsi yang cukup jernih. Bila waktu emulsifikasi lebih dari 2 menit akan menghasilkan sistem emulsi yang keruh, sehingga tidak direkomendasikan untuk formulasi SNEDDS (Makadia dkk., 2013). Uji waktu emulsifikasi dilakukan pada medium akuades pada suhu $37 \pm 0,5^{\circ} \mathrm{C}$. Hasil uji waktu emulsifikasi SNEDDS Minyak Buah Merah terdapat pada Tabel 3.

Tabel 3. Hasil Uji Waktu Emulsifikasi SNEDDS Minyak Buah Merah

\begin{tabular}{ccccc}
\hline Formula & \multicolumn{3}{c}{ Komposisi } & $\begin{array}{c}\text { Rata-rata } \\
\text { Waktu }\end{array}$ \\
\cline { 2 - 4 } & MBM (\%) & $\begin{array}{c}\text { Tween } 80 \\
(\%)\end{array}$ & $\begin{array}{c}\text { Propilen } \\
\text { glikol }(\%)\end{array}$ & $\begin{array}{c}\text { emulsifikasi (detik) } \pm \text { SD } \\
\text { em }\end{array}$ \\
\hline 1 & 9 & 62 & 29 & $16,51 \pm 0,175$ \\
2 & 9 & 68 & 23 & $15,40 \pm 0,272$ \\
3 & 11 & 64 & 25 & $17,64 \pm 0,194$ \\
4 & 12 & 65 & 23 & $18,67 \pm 0,180$ \\
\hline
\end{tabular}

Keterangan : nilai signifikansi $<0,05$ pada semua formula. Ada perbedaan bermakna antar 4 formula SNEDDS Minyak Buah Merah terhadap nilai waktu emulsifikasi yang diperoleh.

Hasil uji waktu emulsifikasi menunjukkan bahwa formulasi tersebut berhasil membentuk SNEDDS Minyak Buah Merah karena dapat terdispersi dalam waktu kurang dari 1 menit. Sistem ini masuk dalam kategori kelas 2, dimana waktu emulsifikasi yang terbentuk cukup cepat dengan menghasilkan sistem emulsi yang jernih (Belhadj dkk., 2013). Hal tersebut menunjukkan ukuran droplet yang terbentuk sudah dalam ukuran nano karena semakin jernih maka semakin kecil ukuran dropletnya.

Pada formula 2 diperoleh waktu emulsifikasi yang paling cepat yaitu 15,40 detik diikuti dengan formula 1 yaitu 16,51 detik, keduanya memiliki komposisi minyak yang sama sebesar 9\% namun komposisi surfaktan pada formula 2 lebih banyak dibanding pada formula 1. Semakin cepat waktu emulsifikasi yang dihasilkan menunjukkan SNEDDS yang semakin jernih, dengan \% Transmitan lebih besar maka semakin kecil pula ukuran dropletnya. Hal ini dipengaruhi karena komposisi surfaktan yang semakin banyak sehingga mampu mempercepat pembentukan emulsi ketika kontak dengan medium (akuades). Pada formula
3 dan 4 komposisi minyak semakin besar sedangkan komposisi surfaktan semakin kecil, sehingga kurang mampu mengikat minyaknya, maka waktu yang diperlukan untuk terbentuknya emulsi semakin lama.

\section{Nilai IC $_{50}$}

Uji sitotoksik adalah uji yang dilakukan untuk mengetahui kemampuan suatu senyawa dalam memberikan efek toksik terhadap sel dengan menggunakan parameter $\mathrm{IC}_{50}$. Metode untuk melihat efek sitotoksik pada penelitian ini adalah metode kolorimetrik menggunakan suatu substrat yang akan dimetabolisme oleh sel menjadi produk berwarna yaitu metode MTT. Senyawa MTT diabsorpsi oleh sel hidup dan direduksi oleh sistem reduktase suksinat tetrazolium yang ada dalam rantai respirasi mitokondria menjadi formazan berupa zat warna ungu (Doyle \& Griffiths, 2000). Semakin banyak sel yang hidup akan memberikan warna larutan dalam sumuran lebih biru-ungu (Meiyanto dkk., 2006).

Intensitas warna ungu dibaca dengan ELISA reader pada panjang gelombang $595 \mathrm{~nm}$. Gambar sel T47D setelah pemberian MTT dapat dilihat pada Gambar 1. 


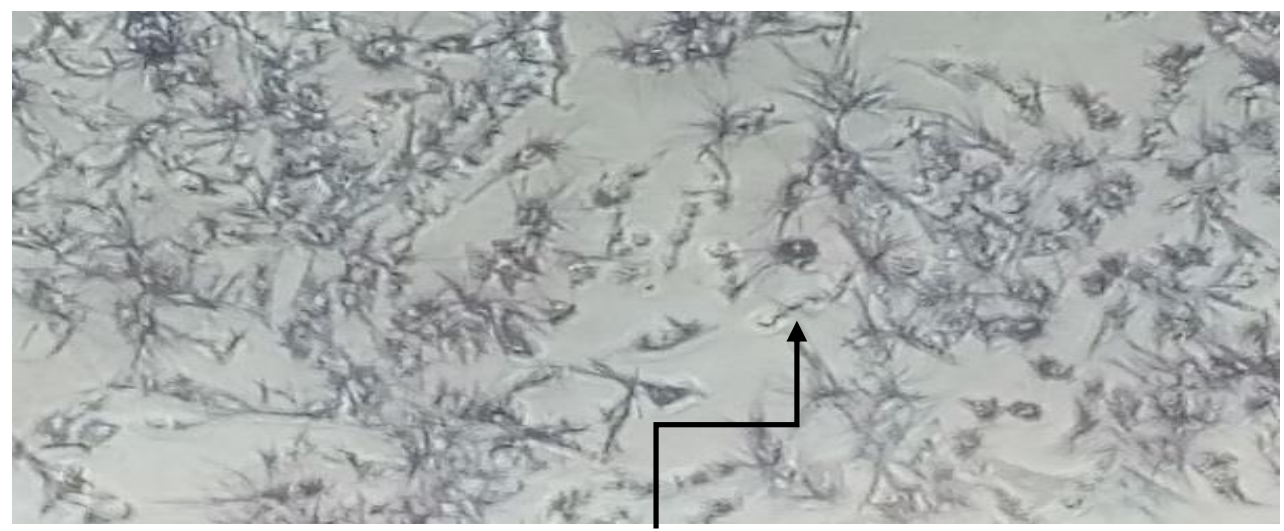

Kristal formazan

Gambar 1. Kristal formazan SNEDDS Minyak Buah Merah dari Sel T47D setelah pemberian MTT

Berdasarkan Gambar 1 menunjukkan adanya pembentukan kristal formazan yang berwarna ungu dan berbentuk seperti jarum setelah pemberian MTT. Semakin banyak kristal formazan yang terbentuk menunjukkan semakin banyak sel yang masih hidup, karena MTT hanya akan bereaksi dengan sel hidup membentuk kristal formazan (Doyle \& Griffiths, 2000). Uji sitotoksik digunakan untuk menentukan nilai $\mathrm{IC}_{50}$ (Inhibitory Concentration). $\mathrm{IC}_{50}$ merupakan konsentrasi yang dapat menunjukkan kemampuan senyawa dalam menghambat pertumbuhan sel sebanyak 50\%. Nilai $\mathrm{IC}_{50}$ menunjukkan potensi suatu senyawa sebagai sitotoksik. Semakin kecil harga $\mathrm{IC}_{50}$ maka senyawa tersebut semakin toksik dan sebaliknya jika semakin besar harga $\mathrm{IC}_{50}$ maka senyawa tersebut semakin tidak toksik (Padmi, 2008).

Nilai $\mathrm{IC}_{50}$ diperoleh dengan persamaan regresi linear $(y=b x+a)$ dari grafik antara log konsentrasi versus $\%$ sel hidup dimana nilai $r$ dikatakan linear jika lebih besar dari $\mathrm{r}_{\text {tabel }}$ kemudian dimasukkan nilai $\mathrm{y}=50$ pada persamaan regresi linear dan dicari $\mathrm{x}$ nya, kemudian dihitung antilog dari konsentrasi tersebut maka diperoleh $\mathrm{IC}_{50}$ (Anonim, 2009). Nilai IC50 SNEDDS Minyak Buah Merah pada berbagai formula tersaji pada Table 4.

Tabel 4. Hasil Perhitungan $\mathrm{IC}_{50}$ SNEDDS Minyak Buah Merah

\begin{tabular}{ccccc}
\hline & \multicolumn{3}{c}{ Komposisi } & $\begin{array}{c}\text { Rata-rata } \\
\text { Formula }\end{array}$ \\
\cline { 2 - 4 } & MBM $(\%)$ & $\begin{array}{c}\text { Tween } 80 \\
(\%)\end{array}$ & $\begin{array}{c}\text { ropilen glikol } \\
(\%)\end{array}$ & IC $_{50}(\mu \mathrm{L} / \mathrm{mL}) \pm \mathrm{SD}$ \\
\hline 1 & 9 & 62 & 29 & $176,81 \pm 1,44$ \\
2 & 9 & 68 & 23 & $58,99 \pm 76,35$ \\
3 & 11 & 64 & 25 & $6832,02 \pm 144,60$ \\
4 & 12 & 65 & 23 & $514,84 \pm 87,59$ \\
\hline
\end{tabular}

Pada penelitian uji sitotoksik SNEDDS Minyak Buah Merah terhadap sel T47D dari formula 1 hingga formula 4 diperoleh nilai rata-rata $\mathrm{IC}_{50}$ secara berturut adalah 176,$81 ; 58,99 ; 6832,02$ dan $514,84 \mu \mathrm{L} / \mathrm{mL}$. Nilai $\mathrm{IC}_{50}$ dari formula 1,3 dan 4 tergolong tinggi karena menurut Meiyanto dkk., (2008) suatu senyawa uji memiliki potensi sebagai agen kemopreventif jika memiliki nilai $\mathrm{IC}_{50}$ kurang dari $100 \mu \mathrm{g} / \mathrm{L}$. Hal ini menunjukkan bahwa 3 dari 4 formula SNEDDS yang dibuat dengan perbandingan Minyak Buah Merah dengan Tween 80 sebagai surfaktan dan propilen glikol sebagai kosurfaktan tersebut kurang mempunyai aktivitas sitotoksik terhadap sel T47D secara in vitro.
Pada penelitian Nuringtyas dkk., (2014), ekstrak metanol buah merah mempunyai nilai $\mathrm{IC}_{50}$ sebesar $132,83 \mu \mathrm{g} / \mathrm{mL}$ terhadap sel T47D, bila dibandingkan dengan $\mathrm{IC}_{50}$ yang diperoleh dari uji sitotoksik SNEDDS Minyak Buah Merah terhadap sel T47D pada formula 2 sebesar $58,99 \mu \mathrm{L} / \mathrm{mL}$ maka SNEDDS Minyak Buah Merah formula 2 mempunyai aktivitas sitotoksik yang lebih besar terhadap sel T47D. Dari penelitian tersebut dapat diketahui bahwa formula 2 SNEDDS Minyak Buah Merah dengan persentase Minyak Buah Merah 9\%, Tween 80 68\% dan propilen glikol 23\% memiliki aktivitas sitotoksik terhadap sel T47D secara in vitro. Formula 2 menunjukkan aktivitas 
sitotoksik yang terbaik, sesuai dengan hasil \% Transmitan dan waktu emulsifikasi.

Jika dilihat dari rata-rata nilai $\mathrm{IC}_{50}$ yang dihasilkan terdapat perbedaan. Namun, dengan analisis statistik dibuktikan bahwa tidak terdapat perbedaan bermakna, hal tersebut disebabkan karena nilai standar deviasi yang dihasilkan nilainya sangat besar perbandingannya dari keempat formula. Hal ini dapat disebabkan karena pengujian SNEDDS dengan bahan dasar minyak kurang baik dilakukan pada keadaan in vitro, karena pelarut DMSO yang digunakan kurang dapat bercampur dengan senyawa uji yaitu SNEDDS Minyak Buah Merah. Maka untuk selanjutnya perlu dilakukan uji aktivitas sitotoksik secara in vivo untuk mengetahui nilai $\mathrm{IC}_{50}$ nya.

Dari hasil penelitian keempat formula bila dilihat dari hasil $\mathrm{IC}_{50}$ nya maka diperoleh formula SNEDDS yang mempunyai aktivitas sitotoksik pada formula 2 . Dari hasil sebelumnya pada uji \% Transmitan dan uji waktu emulsifikasi juga diperoleh hasil yang paling baik adalah formula 2. Maka dapat disimpulkan dari formula 2 diperoleh karakter SNEDDS yang baik dengan perbandingan komposisi yaitu Minyak Buah Merah 9\%, Tween $8068 \%$ dan propilen glikol 23\%.

\section{KESIMPULAN}

Terdapat pengaruh perbandingan persentase Minyak Buah Merah, Tween 80 dan propilen glikol dari 4 formula terhadap nilai \% Transmitan dan waktu emulsifikasi (sig < 0,05), tetapi tidak berpengaruh terhadap nilai $\mathrm{IC}_{50}$ pada uji aktivitas sitotoksik secara in vitro ( $\mathrm{sig}>0,05)$. Dari 4 formula diperoleh karakter SNEDDS yang paling baik pada formula 2 dilihat dari \% Transmitan yang paling besar yaitu 99,34\%, waktu emulsifikasi yang paling cepat yaitu 15,40 detik dan nilai $\mathrm{IC}_{50}$ yang paling kecil yaitu $58,99 \mu \mathrm{L} / \mathrm{mL}$.

\section{DAFTAR PUSTAKA}

Amrutkar, C., Salunkhe \& K., Chaudhari, S. (2014). Study on Self Nano Emulsifying Drug Delivery System of Poorly Water Soluble Drug Rosuvastatin Calcium. World Journal of Pharmaceutical Researc; 3(4); 2137-2151.

Bali, V., Ali, M. \& Ali, J. (2010). Study of Surfactant Combinations and Development of a Novel Nanoemulsion for Minimising Variations in Bioavailability of Ezetimibe. Colloids and Surfaces Biointerfaces; 76; 410-420.

Belhadj, Z., Suyang, Z., Wenli, Z. \& Junlin, W. (2013). Formulation Development and Bioavailability Evaluationof a Self-Nanoemulsifying Drug
Delivery System (SNEDDS) of Atorvastatin

Calcium, International Journal of Pharmaceutics; 29(1); 2051-5782.

Budi, I. M. \& Paimin, F. R. (2005). Buah Merah, Penebar Swadaya. Jakarta.

Chintalapudi, R., Murthy, T. E. G., Lakshmi, R. K \& Manohar, G. G. (2015). Formulation, Optimization, and Evaluation of SelfEmulsifying Drug Delivery System of Nevirapine. International Journal of Pharmaceutical Investigation; 5(4); 205-213.

Date, A., Desai, N., Dixit, R. \& Nagarsenker, M. (2010). Self-nanoemulsifying drug delivery systems: formulation insights, applications and advances. Nanomedicine (Lond.); 5(10); 15951616.

Doyle, A. \& Griffiths, J. B. (2000). Cell and Tissue Culture for Medical Research. New York: John Willey and Sons Ltd; 307 - 309; 311 - 312.

Fakultas Farmasi UGM. (2009). Prosedur Tetap Uji Sitotoksik Metode MTT. Yogyakarta: CCRC.

Hamid, I. S. (2008). Histopatologi dan Aktivitas Proliferasi Sel Kelenjar Mammae Setelah Pemberian Ekstrak Rimpang Temu Putih Curcuma zedoaria dan Inisiasi DMBA (Dimethylbenzen9antrasen) pada Tikus Galur Sprague dawley. Veterina Medika; 1(3).

Harumawati, Sri. (2016). Optimasi Formula SNEDDS (Self-Nano Emulsifying Drug Delivery System) Minyak Buah Merah (Pandanus conoideus Lam) dengan Metode Simplex Lattice Design. Skripsi; Universitas Ahmad Dahlan, Yogyakarta.

Jong, Wim de. (2002). Kanker, Apakah Itu? Pengobatan, Harapan Hidup, dan Dukungan Keluarga. Jakarta: Arcan.

Kaur, G., Pankaj, C. \& Halikumar, S. L. (2013). Formulation Development of SelfNanoemulsifying Drug Delivery System (SNEDDS) of Celecoxib for Improvement of Oral Bioavailability. Pharmacophore; 4(4); 120133.

Kommuru, T. R., Gurley, B., Khan, M. A. \& Reddy, I. K.. (2001). Self Emulsifying Drug Delivery System (SEDDS) of Coenzyme Q10: Formulation for Enhanced Bioavailability Assessment. International Journal of Pharmacy; 212; 233-246.

Makadia, H. A., Bhatt, A. Y., Parmar, R. B., Paun, J. S. \& Tank, H. M. (2013). Self-Nanoemulsifying Drug Delivery System (SNEDDS): Future Aspects. Asian J. Pharm. Res; 3(1); 21-24. 
Mangan, Y. (2003). Cara Bijak Menaklukkan Kanker. Jakarta: PT Agromedia Pustaka.

Meiyanto, E. S., Da'i, M. \& Agustina, D. (2006). Efek antiproliferatif pentagamavumon - terhadap sel kanker payudara T47D. Laporan Hasil Penelitian; Universitas Gadjah Mada, Yogyakarta.

Meiyanto, E., Ratna, A., Sri, H. \& Fitri, R. (2008). Ekstrak Etanolik Biji Buah Pinang (Areca catechu) mampu menghambat poliferasi dan Pemacu Apoptosis sel MCF-7. Majalah Farmasi Indonesia; 19(1); 12-19.

Moeljopawiro, S., Anggelia, M. R., Ayuningtyas, D., Widaryanti, B., Sari, Y. \& Budi, I.M. (2007). Pengaruh Sari Buah Merah (Pandanus conoideus lamk.) terhadap Pertumbuhan sel Kanker Payudara dan Sel Kanker Usus Besar. Berkala Ilmiah Biologi; 6(2); 121-130.

Noviyanti, L. (2010). Modifikasi Teknik Kromatografi Kolom untuk Pemisahan Trigliserida dari Ekstrak Buah Merah. Skripsi; UNS, Surakarta.

Nuringtyas, T. R., Pratama, Y., Galih \& Wahyuono, S. (2014). Cytotoxicity of Buah Merah (Pandanus conoideus Lamk.) Extract on Breast Cancer Cell Line (T47D). Indonesian Journal of Biotechnology Gadjah mada University, Yogyakarta.

Padmi, A. (2008). Uji Sitotoksik Ekstrak Etanol 70\% Buah Kemukus (Piper cubeba L.) terhadap Sel HeLa. Skripsi; Universitas Muhammadiyah Surakarta.

Patel, P. K., Patel, M. R. \& Patel, K. R. (2014). Design and Development of Self-Microemulsifying Drug Delivery System of Febuxostat. International Journal of Universal Pharmacy and Bio Sciences; 3(2); 285-299.

Rawat, S., Derle, D. V., Parve, B. S. \& Shinde, P. R. (2014). Self Emulsifying Drug Delivery System (SEDDS): A Method for Bioavailability Enhancement, International Journal of Pharmaceutical, Chemical And Biological Sciences; 4(3); 479-494.

Rohman, A., Sugeng, R. \& Che Man, Y. B. (2012). Characterization of red fruit (Pandanus conoideus Lam.) oil. International Food Research Journal; 19(2); 563-567.

Rowe, R. C., Sheskey, P. J. \& Owen S. C. (2009). Handbook of Pharmaceutic exipients $6^{\text {th }}$ edition. London: Pharmaceutical Press and American Pharmascists Assosiciation; 549-679.
Sahumena, M. H. (2014). Pengembangan Nanopartikel Ketoprofen dengan Teknik SNEDDS dan Uji Aktifitas Antiinflamasi. Tesis Program Pasca Sarjana; Universitas Gadjah Mada, Yogyakarta.

Shargel, L., Pong, S. W. \& Yu. A. B. C. (2005). Applied Biopharmaceutics and Pharmacokinetics Ed V, 411-450. The McGrawHill, Singapore.

Sinaga, E., Suprihatin \& Wiryanti, I. (2011). Perbandingan Daya Sitotoksik Ekstrak Rimpang 3 Jenis Tumbuhan Zingiberaceae Terhadap Sel Kanker T47D. Jurnal Farmasi Indonesia; 5(3); 125-133.

Singh, B., Bandopadhyay S., Kapil R., Singh R. \& Katare O. P. (2009). Self-Emulsifying Drug Delivery Systems (SEDDS): Formulation Deveploment, Characterization, and Applications. Critical Reviews in Therapeutic Drug Carrier Systems; 26(5); 427-521.

Sumarawati, T. \& Fatmawati. (2011). Isolasi dan Uji Sitotoksik Senyawa Alkaloid Mahkota Dewa (Phaleria macrocarpa) Pada Kultur Sel Kanker Payudara (T47D). Prosiding Semnas Herbs For Cancer; 102-110.

Sun, M. \& Han, J. (2011). Design, Preparation and In Vitro Evaluation of Paclitaxel-Loaded SelfNanoemulsifying Drug Delivery System. Asian Journal of Pharmaceutical Science; 6(1); 18-25.

Tjindarbumi, D. \& Mangunkusumo, R. (2002). Cancer in Indonesia, Present and Future. Japan Journal of Clinical Oncology; 32 (1); S17-S21.

Xi, J., Chang, Q., Chan, C, K., Meng, Y., Wang, G, N., Sun, J. B., Wang, Y, T., Tong, H. Y. \& Zgheng, Y. (2009). Formulation Development and Bioavailability Evaluation of a SelfNanoemulsified Drug Delivery System of Oleanolic Acid. AAPS Pharmaceutical Science and Technology; 10(1); 172-182.

Zhao, T. (2015). Self-Nanoemulsifying Drug Delivery System (SNEDDS) for the Oral Delivery of Lipophilic Drugs. Thesis Departement Industrial Engineering; University of Trento, Italy. 